\title{
CHINESE LAW. A FOUR-KEYNOTE \\ WHEN DEALING WITH CHINESE PARTNER (LIQUIDATED DAMAGES, ERR, DISPUTE AND CHOP)
}

\section{Introduction}

To study what in the Western countries would be called Chinese private law, one should consider and explore Chinese customs and traditions. The law (s) in the books ${ }^{1}$ is not ample or sufficient to effectively and with understanding navigate through Chinese law $^{2}$ at all, since it might lead, in particular, foreign enterprise to err. One must go beyond this and search for Chinese traditions, customs or entrenched practices. As Lon L. Fuller in "Human Interaction and the Law" advances, one cannot understand "ordinary law" (meaning officially declared or enacted laws) unless one first obtains an understanding of what is called "customary law". ${ }^{3}$ An enterprise dealing with a Chinese partner, therefore, that chooses to ignore all but the laws in the books or ordinary law is choosing to work half blind.

This article sets forth an introductory communication of how to navigate through Chinese Law, in particular, unified 1999 Chinese Contract Law, finding one of many possible ways how to supplement law $(s)$ in the books, in order to ease half blind foreigner or enterprise with the understanding and using law of People's Republic of China. Indeed, having laws (in China) is one issue, having them fully and properly implemented is another. ${ }^{4}$ Chinese people do not recognize law

1 In this article law(s) in the books is an opposed attribute of practical legal and law-in-action approach, highlighting that law in the books remains only on paper and is not alive nor it is used or exercised by society.

2 In using term "Chinese Law", "Chinese contract law", "law of China" or the like, it is referred herein only to the laws of mainland China, while the laws of Hong Kong Special Administrative Region, Macao Special Administrative Region and Taiwan are not considered for the purpose hereof.

3 L.L. Fuller, Human Interaction and the Law [in:] The Rule of Law, ed. R.P. Wolff, New York 1971, pp. 172-173.

4 Jianfu Chen, Chinese Law: Context and Transformation, Revised and Expanded Edition, Leiden-Boston 2015, pp. 965-1018. 
as a major vehicle for assuring peace or social order. ${ }^{5}$ On this score, legislation was never anything but complementary in Chinese social order or dispensable proving that society can leave without law and lawyers. ${ }^{6}$ The initial findings of this article, are to provide lessons that can be drawn for people dealing with Chinese partner in their best route to achieving goals for legal transaction and business exchange to happen, but at the same token, to leave the readers to make their own judgements and recognition on this law development and implementation in contemporary China.

The article proceeds as follows. Part "Liquidated Damages. Err. Dispute Settlement" includes and introduces of how to use and exercise liquidated damages clause in contractual dealings, ending with a practical keynote in order to move onto the concept of contractual default (as I named it a "concept of err") and dispute settlement with "Chinese characteristics." Part titled "Chop" provides short and concise information on technical signing and chopping contracts, at the same providing an answer to the question on the contract effectiveness. Last Part concludes and provides trends for further research of the paramount importance of looking for the Chinese law better understanding through Chinese characteristics.

The article makes no claim to be completely comprehensive in scope, nor does imply that issues covered herein below are the only, full and complete elements when contracting with a Chinese partner. As such, the coverage proves that relying only on the law in the books will not end up with full and successful cooperation with a Chinese partner. Here lies the significance of the recognition of Chinese practice, traditions and customs seen as a necessity for effective contracting as the Chinese law develops and new business opportunities emerge.

\section{Liquidated Damages. Err. Dispute Settlement}

In this Part, I advance three key issues often encountered by a foreign enterprise when dealing with Chinese partner.

First, liquidated damages (违约金, wéiyue jīn), a well-recognized international contractual clause, whereon the parties may stipulate that in the event of default, defaulting party shall be held liable to pay a stipulated amount of money to the non-defaulting party. Parties may provide a fixed amount of money, certain formula or percentage value, for instance, $5 \%$ calculated from the total amount of contract value or price. The same happens in Chinese Contract Law that reads:

5 J.M. Otto, Conclusion: A Comparativist's Outlook on Law-Making in China [in:] Law-Making in the People's Republic of China, eds. J.M. Otto, M.V. Polak, Jianfu Chien, Yuwen Li, The Hague-London-Boston 2000, p. 261.

${ }^{6}$ A. Kość, Prawo a etyka konfucjanskea w bistorii myśli prawnej Cbin, Lublin 1998, p. 233. 
当事人可以约定一方违约时应当根据违约情况向对方支付一定数额的违约金, 也可以约定因违约产生的损失赔偿额的计算方法。[The parties may agree upon should one party breaches the contract, it shall pay a certain sum of liquidated damages to the other party in light of the circumstances of the breach; parties may also agree upon on a method for the calculation of the amount of compensation for the damages incurred as a result of the breach - translated by M.P. $]^{7}$

However, worth noting is that the Chinese Law expressly provides the possibility by the Chinese court to interfere with the already agreed by the parties contractual amount of money as for the liquidated damages. Such situation may occur should one of the party deems that the amount of loss that the party sustained is higher than the amount already provided in the contract. In other words, the party may lodge an application to the court or arbitration institution (petition) to reduce or increase the value of the liquidated damages to an appropriate level. ${ }^{8}$

From a practical point of view, it should be noted that the amount of the liquidated damages, is never sure. However, from grounded practice determination of the amount of the liquidated damages at the moment of entering into the contract, may lead to smoother and faster proceeding as for the court to a establish value of the dispute and nature of the proceeding. An indication of the amount of the liquidated damages in a contract serves as a guide for the court to be able to have a point of reference. Presumably, there are good reasons to argue that placing the record of liquidated damages may give an incentive or motivate both parties to the contract performance.

To sum up, it is worth ensuring to have liquidated damages in the amount that is not too high and not too low (genuine pre-estimation of damages). With this approach, parties may mitigate the risk of any possible scenario to deem the clause of liquidated damages by a court as null and void.

Second, even more, noteworthy is the concept of contractual default when dealing with a Chinese partner and for a good navigation of the Chinese contract. One may pose a question: upon when the liquidated damages may be enforced or due. This cannot be answered without paying attention to the Confucian tradition predominant traditional ideology on the development of law. ${ }^{9}$ Confucian heritage, nowadays, is perceived much more seriously. In modern China, more and more attention is paid to the political system based on Confucian tradition, the concept of the Confucian constitution, ${ }^{10}$ to name just a few. Many initiate and carry on in an

7 Article 114 of the Chinese Contract Law, 中华人民共和国合同法。Zhōnghuá rénmín gònghéguó hétóng fă [Contract Act] (1999) (P.R.C.), http://www.npc.gov.cn/wxzl/wxzl/2000-12/06/content_4732.htm (accessed: 23.08. 2017).

8 See in fine article 114 of the Chinese Contract Law.

9 Confucius (孔子, Kǒngæ̌ ever in the world and enjoys worldwide fame.

10 See: M. Stępień, Chińskie marženie o konstytucjonaliżmie, Kraków 2015. 
attempt to find the new, original way of development of political system and law in China (and other countries of the similar roots) on the grounds of new Confucian tradition circumstances. True, full and complete performance of the contract has always been emphasized by Chinese contract law but reflecting and reinforcing certain limitations on freedom of contract. Former Chinese contract law (before 1999) emphasized such performance. Thus, parties to a contract were required to fully do, perform and discharge their obligations as set forth in the contract; neither party was permitted to arbitrary alter, change, amend or dissolve the contract. ${ }^{11}$ Yet, when performing contractual duty, interesting findings may occur with the idea of "Err", the quotation from Analects of Confucius ${ }^{12}$ is provided:

子日: “过而不改, 是谓过矣。”

The Master (孔子, Kǒngq̨ l’ ${ }^{13}$ ) said, "Not to mend one’s ways when one has erred is to err indeed." ${ }^{14}$

The hereinabove quoted Confucius teaching addresses the self-improvement. In Chinese culture, one of the key prerequisites of self-improvement is an ongoing correction of errors, wrongdoing or mistakes. Confucius maintained that man has a wide spectrum of disadvantages, drawback or constantly errs. Thus, self-improvement is an ongoing process of correction of once own mistakes and wrongdoing. Error, that can be cleared or corrected is not an error. According to the foregoing teachings of Kongri, well entrenched in China, I strongly believe in such rule a foreigner enterprise should be well acknowledged thereof. A clear example that disputes, claims or irregularities may arise between Western and Chinese Party is perceiving of making errors when performing contracts. Western party will automatically initiate collecting for example liquidated damages and Chinese would claim no error at all since error has been corrected.

Thereafter, a dispute by and between the foregoing parties may arise. In the wake of the above, given the chance to provide a one-sentence description of dispute settlement in China I would support: settlement dispute in court should be treated as a last resort and a place to be avoided at all costs. ${ }^{15}$ The court (衙门, yámén), as it was known, had traditionally been the office of magistrates, who owed

11 See: article 6 of the Economic Contract Law of the People's Republic of China of 1981(ECL); Article 16 of the Law of the People's Republic of China on Economic Contracts Involving Foreign Interests of 1985 (FECL); and article 88 of the General Principles of Civil Law of the PRC (GPCL) of 1986.

12 The Analects (论语, Lúny ü) are the only original source of Kongzi knowledge that have survived to this day. Limyǔ is a valuable source of information about social and cultural life of China.

13 See: M. Stępień, Chińskie marzenie...

14 Book 15.30 of the Confucius Analects. Confucius: The Analects (Chinese/English) 论语 (中英文 对照), trans. by Yang Bojun (Modern Chinese), D.C. Lau (English), Beijing 2010, pp. 290-291.

15 E. Lee, Commercial Disputes settlement in China, London 1985, p. 3. 
their position to passing imperial examinations. These magistrates were trained in literature, poetry and art, and few were masters of law. Their functions included the collection of taxes and other duties delegated by the central government. A suit in the yamen was widely held as degrading and humiliating and on many occasions ruined both parties involved. The shame and fear attached to the yamen naturally caused people to keep their distance, even today. Book 12.13. from Analects of Confucius is a good case point and reads:

\section{子日: “听讼, 吾犹人也。必也使无讼乎!”}

The Master (孔子, Kong $2 i^{16}$ ) said, "In hearing litigation, I am no different from any other man. But if you insist on a difference, it is perhaps, that I try to get the parties no resort to litigation in the first place." ${ }^{17}$

The above reflects the cornerstone practice in China, i.e. one of the most important activity and task for the ruling bodies is to hear a case and resolve disputes, claim or controversy, however, with a perfectly governed country, based on 仁 Rén (righteousness), there should be no litigation at all. Consequently, mediation, negotiation, conciliation and any other alternative dispute resolution appears to have a long history in China, and today is often used by parties.

Needless to say that the parties are required to perform their obligations, and should a dispute arise, the courts are to enforce the terms and conditions that have been agreed upon by the parties. To the contrary, from a Chinese perspective, the signing and execution of a contract indicates just the beginning of the business relationship; it anticipates rather than defines the resulting relationship. ${ }^{18}$ Although not meaningless, considerably less importance is attached to the contractual terms. Parties are expected to make mutual adjustments and accommodations in response to the events that occur. Contracts are "considered unnecessary, sometimes offensive, when rules of loyalty and mutual obligation govern the business environment". ${ }^{19}$ The Chinese often regard the written contract as a formality, leading them to frequently ignore it. ${ }^{20}$

16 M. Stępień, Chinskie marzenie...

17 Book 12.13 of the Confucius Analects. Confucius: The Analects (Chinese/English) 论语 (中 英文对照), translated by Yang Bojun (Modern Chinese) and D.C. Lau (English), Beijing 2010, pp. 212-213.

18 See: P. Pattison, D. Herron, The Mountains are High and the Emperor is Far Away: Sanctity of Contract in China, "American Business Law Journal" 2003, Vol. 40, pp. 459-510, 491; Ph. McConnaughay, Rethinking the Role of Law and Contracts in East-West Commercial Relations, "Virginia Journal of International Law" 2000, Vol. 41, p. 446, available at: https://ssrn.com/abstract=252659 (accessed: 14.11.2017).

19 P. Pattison, D. Herron, The Mountains..., pp. 484, 487, 488.

20 Chunlin Leonhard, Beyond the Four Corners of a Written Contract: A Global Challenge to U.S. Contract Law, "Pace. International Law Review" 2009, Vol. 21, No. 1, pp. 1-26, 16, available at: http://digitalcommons.pace.edu/pilr/vol21/iss1/1 (accessed: 14.11.2017). 
For all the above issues that might be encountered by a foreign enterprise when dealing with a Chinese partner, many would add and pinpoint whether the parties effectively executed the contract; and this to be answered in Part III of the article.

\section{Chop}

This Part sketches effective and binding representation of the will within the contracting parties. In China, the company chop or seal constitutes the main means of legally authorizing documentation, serving the same legal effect as the company chief executive's signature. As the famous saying goes: "the controller of the chop is the controller of the company". This little (in the region of $4 \mathrm{~cm}$ in dimension), often wooden red stamp or seal has played a powerful role in Chinese business. ${ }^{21}$ It is obligated for every company registered in China and has to be registered with the Public Security Bureau (PSB). Moreover, for a contract prepared in the written instrument, a company seal or chop shall be affixed to render it valid and enforceable. Indeed, under the Chinese Contract Law:

当事人采用合同书形式订立合同的, 自双方当事人签字或者盖章时合同成立。 [Should the parties conclude a contract in written instrument, the contract is established when signed or sealed by the parties - translated by M.P. $]^{22}$

Moreover, in Chinese Company Law, a corporate seal or chop is required to be affixed on various legal documents such as capital contribution certificate, company stock. ${ }^{23}$

There are a number of different types of chops for various purposes, including

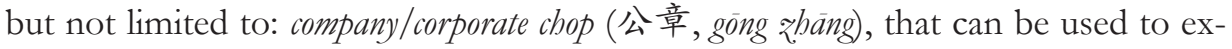
ecute all legal documents and is, therefore, the most important chop. The company chop is usually round in shape and the registered name of the company is engraved at the bottom of the stamp. Once the company is successfully registered with the Administration of Industry and Commerce, ${ }^{24}$ a qualified chop-maker (approved by the local Public Security Bureau) must be engaged to produce the company chop. The Public Security Bureau will then keep a copy of the company's chop for verification in case of dispute or alleged fraud.

${ }^{21}$ Chops date back to 1000 B.C. Yet, during Cultural Revolution, chop holders were displaying their chops by hanging them on their trousers belts in order to display political and economic power among others. For more see, e.g. Yu Hua, China in Ten Words, trans. by A.H. Barr, Warsaw 2013.

22 See: article 32 of the Chinese Contract Law.

23 See for example articles 25 and 31 of the Chinese Company Law.

24 工商行政管理总局, Göngshāng háng zhèng guănlǐ zŏngjü, SAIC. 
Invoice chop (发票章, fäpiào zhāng), that is affixed to invoices issued by the company, is required as evidence of a business expense for the tax authorities. Without the invoice chop, entities or stakeholders cannot furnish or lodge the document within tax authorities as evidence of a business expense. Fapiao chop may be elliptical in its shape.

Worth noting is another, square in shape chop. i.e. legal representative chop (法人 代表章, färén däibiăo zhāng) used by the company's legal representative. It has to be registered with the Administration of Industry and Commerce. ${ }^{25}$ It is generally used together with the company/corporate chop for many official documents, applications or communications, such as an application for the company's business license. The chop has the name of the company's legal representative carved into its face. In most cases, this legal representative is either the owner, the chief executive or a board member of the company. The chop is also filed with the local Administration of Industry and Commerce. ${ }^{26}$

To give some guidance to the parties contracting with a Chinese partner whether the contract the parties have is technically signed correctly and legally enforceable, a foreign enterprise should be aware of the essential principles: every Chinese company has only one "legal representative", and the company's business license states who this is. Any contract executed by the legal representative is binding, whether or not a chop is attached thereto. Any contract with the company chop is also binding, regardless of who signed on behalf of the company. The dream scenario is to have the contract both signed by the legal representative and chopped with the company chop, all the time highlighting that establishing and maintaining a relationship build on mutual trust and benefit should take a lead in a transaction to happen.

\section{Conclusion}

I recognize that the foreign enterprise dealing with Chinese partner not willing to act and conduct business half blind, should beyond the law (s) in the books, search for and acknowledge with Chinese culture, customs, entrenched practices, try to make sure the contract he or she wants to be enforceable and effective, be executed and chopped by Chinese partner, with the stipulated genuine estimation of liquidated damages and mutual understanding of wrongdoing or err when performing contract and be ready and willing to negotiate contract not only before its signature but most importantly upon its execution and thereafter.

25 P. Pattison, D. Herron, The Mountains...

26 Ibidem. 


\title{
STRESZCZENIE
}

\author{
PRAWO CHIŃSKIE. CZTERY PODSTAWOWE \\ ASPEKTY WSPÓEPRACY Z CHIŃSKIM PARTNEREM \\ (KARA UMOWNA, BEĄD, SPORY I PIECZEĆ)
}

W celu zbadania, co w krajach zachodnich można nazwać chińskim prawem prywatnym, należy rozważyć i zbadać chińskie zwyczaje i tradycję. Law in books nie są wystarczające ani adekwatne, aby skutecznie i ze zrozumieniem poruszać się w chińskim prawie, ponieważ mogłoby to doprowadzić zagraniczne przedsiębiorstwo do błędnych działań. Trzeba wyjść poza nie i szukać chińskiej tradycji, standardowych lub zakorzenionych praktyk. Lon L. Fuller w Human Interaction and the Law wskazuje, że nie można zrozumieć „zwykłego prawa” (co oznacza oficjalnie ogłoszone lub uchwalone prawa), chyba że najpierw zrozumie się to, co nazywa się „prawem zwyczajowym”. Dlatego przedsiębiorstwo współpracujące z chińskim partnerem, które wybiera ignorowanie wszystkiego poza law in books lub zwykłym prawem, decyduje się działać na oślep.

W artykule zawarto wskazówki dotyczące tego, jak poruszać się w chińskim prawie, w szczególności w chińskim prawie umów. Zaprezentowano tu jeden z wielu możliwych sposobów uzupełniania law in books, aby ułatwić działającemu na oślep obcokrajowcowi lub przedsiębiorstwu zrozumienie i sposób stosowania prawa chińskiego. Zagadnienia zawarte w artykule mają na celu dostarczenie osobom współpracującym z chińskim partnerem wskazówek, które pozwolą na osiągnięcie celów związanych z transakcją prawną i wymianą handlową. Jednocześnie artykuł ma umożliwić czytelnikom własną ocenę rozwoju i stosowania prawa we współczesnych Chinach.

Zawarto tu studia przypadków pokazujące implementację prawa o chińskiej specyfice. Przykłady obejmują m.in.: niewywiązanie się z umowy, kary umowne, błąd, spory, problematykę pieczęci. 